\title{
THE EFFECT OF PHYSICAL AND CHEMICAL PARAMETERS ON THE STRUCTURE AND COMPOSITION OF THE PHYTOPLANKTON COMMUNITY OF LAKE BUDI (IX REGION, CHILE)
}

\author{
SILVIA BASUALTO ${ }^{1}$, JAIME TAPIA ${ }^{2 *}$, FABIOLA CRUCES ${ }^{3}$, CARLOS BERTRAN ${ }^{4}$, ROBERTO SCHLATTER ${ }^{4}$, \\ FERNANDO PEÑA-CORTÉS $S^{3}$ AND ENRIQUE HAUENSTEIN ${ }^{5}$
}

\author{
${ }^{1}$ Centro EULA, Universidad de Concepción, Concepción, Chile \\ ${ }^{2}$ Instituto de Química de Recursos Naturales, Universidad de Talca, Talca, Chile \\ ${ }^{3}$ Facultad de Ciencias Naturales y Ocenográficas, Universidad de Concepción, Concepción, Chile \\ ${ }^{4}$ Instituto de Zoología, Facultad de Ciencias, Universidad Austral de Chile, Valdivia, Chile \\ ${ }^{5}$ Facultad de Recursos Naturales, Universidad Católica de Temuco, Temuco, Chile
}

\begin{abstract}
The chemical characteristics of the waters of Lake Budi (IX Region, Chile), in winter and summer were analysed in order to establish seasonal variations and determine their influence on the various phytoplankton components. On the basis of the results it was possible to indicate that the chemical parameters found in the water body under examination vary in time and space, giving rise to different algal communities. The strong influence of salinity on the phytoplankton communities in both study periods appears to result principally from the influence of the sea, resulting from the intrusion of salt water during certain periods of the year. The predominant chemical characteristic in summer indicates a slight reduction in water quality, due to a rise in temperature and a reduction in the oxygen concentration.
\end{abstract}

Keywords: Lake Budi, salinity, phytoplankton, water quality.

\section{INTRODUCTION}

Phytoplankton constitutes the most important primary producer, and is a fundamental food source for consumers in many continental aquatic systems [1-2-3]. However the wide spectrum of organisms of which it is made up and the limnological characteristics which may be encountered in each individual system have hindered understanding of the processes involved in population dynamics [4].

In general, it has been established that the determining factors for the structure of phytoplankton communities in lakes result from the relationship which exists between the physical, chemical and biological parameters present in a water body [5].

Several studies carried out in freshwater environments have established that the growth of phytoplankton may be controlled to a large degree by the limitation of nutrients [6-7], the availability of light [8] and the composition and abundance of zooplankton [9]. It has also been determined that in coastal lakes which are subject to marine influence during some period of the year, salinity may also be a factor affecting the growth and distribution of phytoplankton [10-11]. The above is a consequence of the problems in osmotic regulation produced by the intrusion of sea-water, both for freshwater and marine organisms [12].

Under natural conditions, it has been determined that phytoplankton respond in a regular manner to the variations in their environment which occur in an annual cycle [13-14]. This is largely a consequence of changes to the physical characteristics and the stability of the water column. As a result, the varying algal components of the phytoplankton in a lake are a clear indicator of its environmental state. In this respect, an analysis of the composition and presence of species, their abundance and biomass, can provide the information needed to evaluate the ecological state of lacustrine systems.

However, phytoplankton communities do not respond only to natural changes into the lakes, but may also present variations as a consequence of human interventions affecting the water body, either directly or through activities carried on in the basin as a whole.

These influences affecting the lakes result in modifications to the structure and composition of the phytoplankton, which may take the form of changes in the taxa of which the algal associations are composed, in the abundance of each taxa, the richness and diversity of the associations, and other community parameters. Finally, due to the interdependence existing between the different organisms of which systems are composed, these variations in the phytoplankton communities translate into changes to the trophic chain and the productivity of the lakes [15].
Lake Budi constitutes a coastal lacustrine system where there is a strong marine influence due to the intrusion of salt water during certain periods of the year. Moreover, in recent decades there has been considerable human intervention in the basin. These two characteristics are indubitably determining factors in the physical and chemical conditions of the water column in the lake.

As proposed, the aim of this study was to establish the physical and chemical parameters of the water which have the greatest influence, and which determine the algal associations present in the phytoplankton of Lake Budi.

\section{EXPERIMENTAL}

Area of the study and sample collection

Lake Budi $\left(38^{\circ} 52^{\prime} \mathrm{S} ; 73^{\circ} 18^{\prime} \mathrm{W}\right)$ is a coastal lake which is connected sporadically to the sea. Different bio-types may be recognized in the composition of its surroundings: banks, either covered with vegetation or bare; mud-sand beaches; and sediments with a high content of organic material derived from aquatic plants [16].

Based on the special characteristics of Lake Budi and the contribution of its principal tributaries (Budi, Temo, Allipén, Comué, Bolleco and Botapulli), nine sampling stations were established: Río Budi, Temo, Allipén, Comué, Bolleco, Botapulli, Deume 1, Deume 2 and Deume 3 (Fig. 1).

To account for the marine influence present in Lake Budi, samples were taken at two times of year, the first in July 2004, representing the state of the lake in winter, and the second in January 2005, reflecting summer conditions. Two samples were taken at each sampling station: a surface sample $(20 \mathrm{~cm})$ and a deep sample $(1 \mathrm{~m})$, with the exception of the Río Budi station, where only surface samples were taken due to the shallowness of the water at the time of sampling.

\section{Chemical Analysis}

Eight physical and chemical parameters for water quality were established for this study: temperature, $\mathrm{pH}$, salinity, oxygen in solution (OS), biochemical oxygen demand (BOD), total suspended solids (TSS), organic suspended solids (OSS) and nitrates. These were determined by extracting water samples using a Rüttner bottle, with each sample taken in duplicate. Consideration was given to conditions at sampling, the type of container, preservation and the maximum time-lapse between the taking and the analysis of the sample [17-18]. 


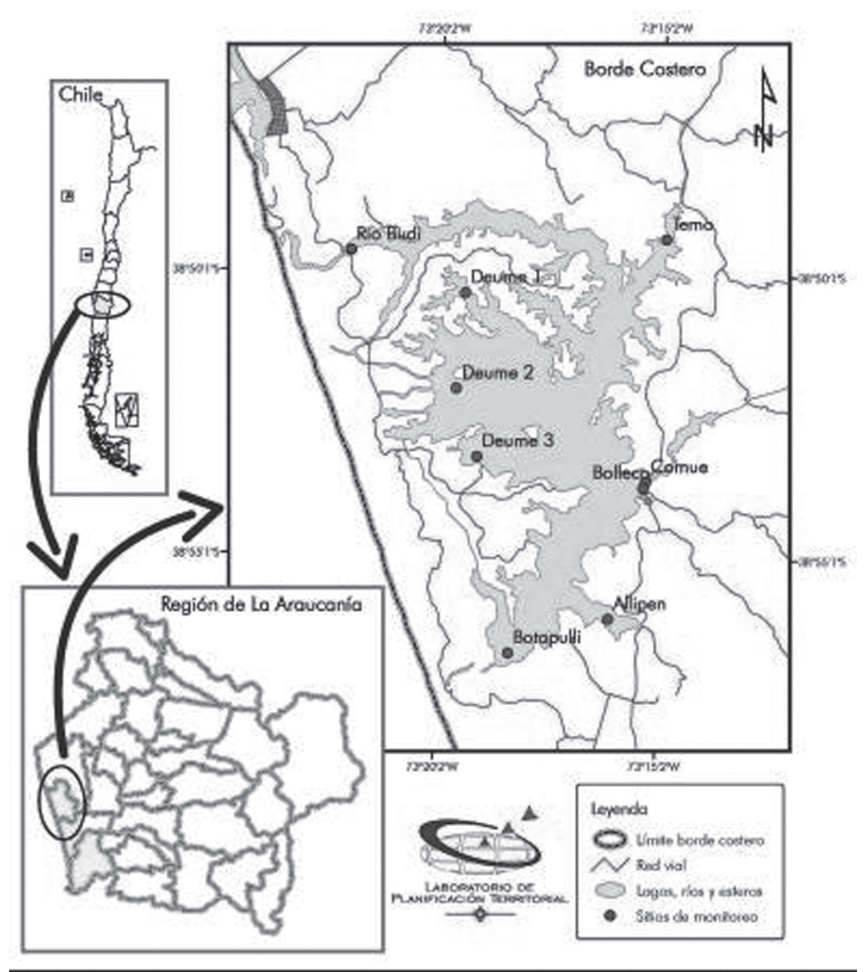

Fig. 1: Geographical location of the nine sampling stations of water and microalgae in Lake Budi.

The following parameters were measured in the field: temperature, $\mathrm{pH}$, salinity, and oxygen fixed in solution using the Winkler method. The equipment used was respectively, a Delta model HD 9212 temperature sensor; a Hanna model HI 9023 pH-meter; and a Hanna model HI 9033 conductivity meter.

The water samples were placed in polythene containers and filtered using polycarbonate systems, with filters of $0.45 \mu \mathrm{m}$ porosity. The filtered samples yielded the nitrate content, while in the unfiltered parallel samples the total solids in suspension were measured and the organic fraction determined. The samples were kept under refrigeration at $4^{\circ} \mathrm{C}$ until the chemical analysis was done.

The methods of analysis used to determine the total solids in suspension, organic solids in suspension, oxygen in solution, BOD and nitrates are those presented by the Standard Methods for the Examination of Water and Wastewater [19 a, b, c].

\section{Biological Analysis}

The analysis of the phytoplankton communities of Lake Budi included both the quantitative and qualitative determination of the algal components present in each samples. This was done using a $2 \mathrm{~L}$ Rüttner bottle and a phytoplankton mesh with a $150 \mu \mathrm{m}$ pore aperture. In each station an aliquot of $100 \mathrm{ml}$ was taken directly from the bottle in the field, and a solution of lugol was added to fix and conserve the microorganisms.

The taxonomic and quantitative determination of the phytoplankton was made using a Karl Zeiss photon microscope and an inverted microscope respectively. In the latter case, the procedure followed was that described by Utermöhl [20]. In some cases an electron microscope was also used, using an ETEC Autoscan U-1 scanning microscope. The literature used in determining the algal groups and species was principally Kramer \& Lange-Bertalot, [21] and Parra [22-23-24].

\section{Data Analysis}

To establish a relationship between the species and the physical and chemical variables, the CANOCO Program (Version 4.5) was used, based on a multivariate analysis. In parallel, diversity was determined through a Shannon Diversity Index for each of the stations.

\section{RESULTS}

\section{Physical and Chemical Parameters}

Fig. 2 shows the variations for the physical and chemical parameters: temperature, $\mathrm{pH}$, salinity, oxygen in solution, biochemical oxygen demand, total suspended solids, organic suspended solids and nitrates, recorded at the nine sampling stations, in surface and deep water of Lake Budi during two sampling periods - July 2004 (winter) and January 2005 (summer).

As would be expected, the temperature variable showed a considerable increase in value in summer as opposed to winter, and most of the stations showed the higher temperatures in the surface samples. The highest value was recorded in the surface water of the Comué station in summer $\left(25.8^{\circ} \mathrm{C}\right)$ and the lowest in the winter period in the surface and deep waters of the Deume 3 station $\left(10^{\circ} \mathrm{C}\right)$. With regard to the $\mathrm{pH}$ variable, values fluctuated between 6.8 -8.2 for the winter period and between 7.0 and 8.9 for the summer period, with a more basic value in all stations during the summer period.

With regard to salinity, it was observed that the Río Budi, Allipén and Deume 1, Deume 2 and Deume 3 stations showed the highest salinity in both sampling periods, being higher at all stations in summer, with values of up to 4.0 PSU. These values are in agreement with the geographical locations of these stations, where there is a marked marine influence due to the intrusion of salt water. At the same time, it was established that this parameter has a strong influence on the distribution and composition of the phytoplankton communities and clearly marks the differences which exist between the different stations monitored (Fig. 3).

The values recorded for oxygen in solution in the winter period were greater than $8.5 \mathrm{mg} / \mathrm{L} \mathrm{O}$ for all the sampling stations. However these values diminished considerably in the summer, varying between 6.0 and $9.0 \mathrm{mg} / \mathrm{L}$ $\mathrm{O}_{2}$. Consistent with the previous point, the BOD parameter shows the highest values in summer, with the highest levels observed in Río Budi, Allipén and Deume 2 stations. For the summer period a general increase in values is observed, especially in the sampling points of the deep zone.

For the total solids in suspension, it was observed that in the winter period there are no major differences between the sampling stations. However in the summer, the values showed an increase, especially in the sampling points of the deep zone. With respect to the concentration of organic solids in suspension, the values are consistent with the BOD values, where the greatest concentrations were recorded in the Temo, Allipén, Comué, Bolleco and Deume 1 stations. Finally, the $\mathrm{N}^{-\mathrm{NO}_{3}}$ variable in general presents greater concentration values in the summer period, being slightly lower in those stations where the concentration of oxygen in solution is lower, and the content of nitrogen is also reduced. The values for nitrate concentrations recorded in Lake Budi would lead to its classification as an oligotrophic or mesotrophic lake system. 

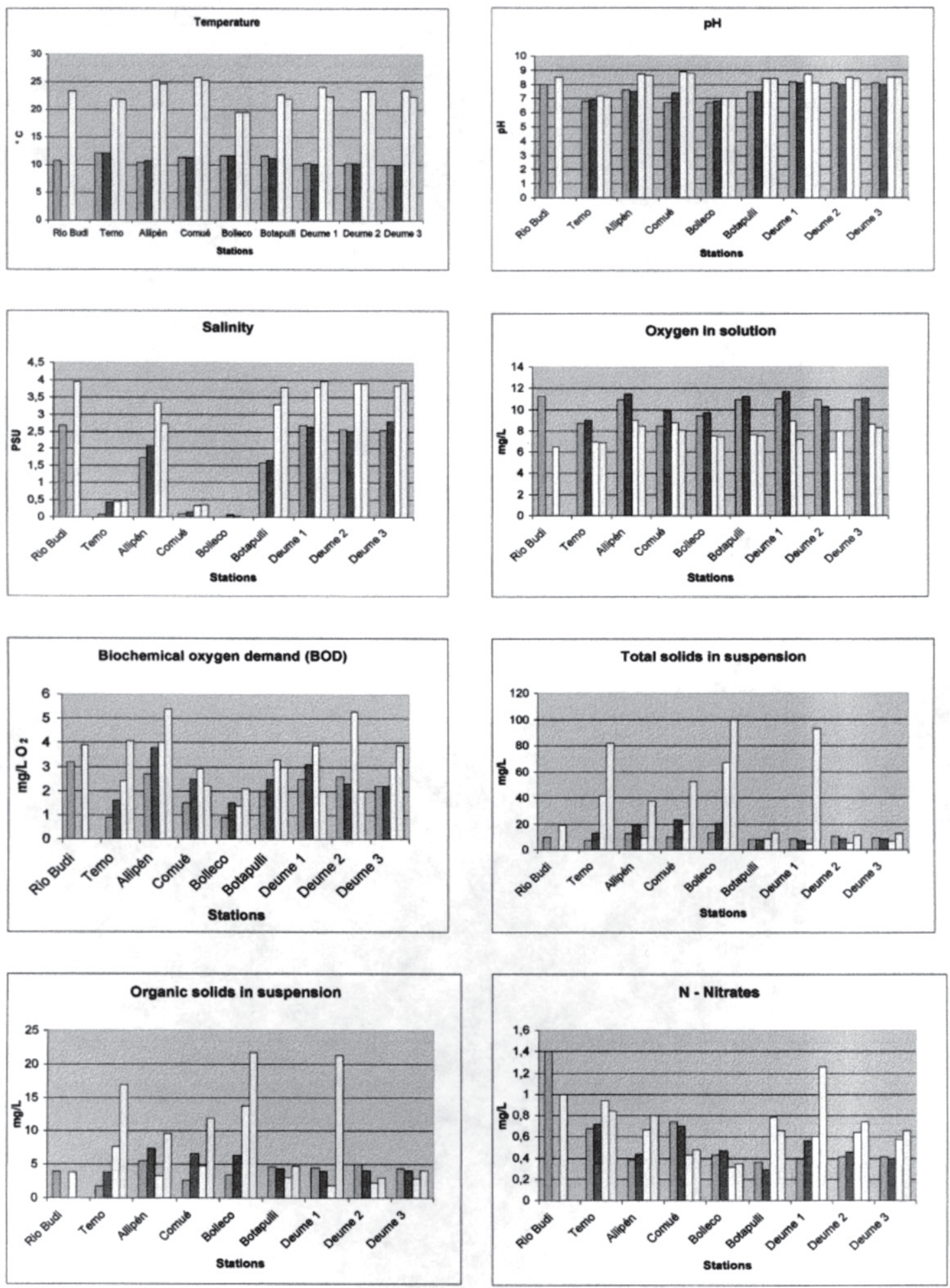

Fig.2: Seasonal variation of the physical and chemical parameters recorded al the nine sampling points or surface and deep waters of Lake Budi.

\begin{tabular}{|l|r|}
\hline$\square \quad$ Winter surface & Winter deep \\
\hline$\square$ Summer surface & Summer deep \\
\hline
\end{tabular}



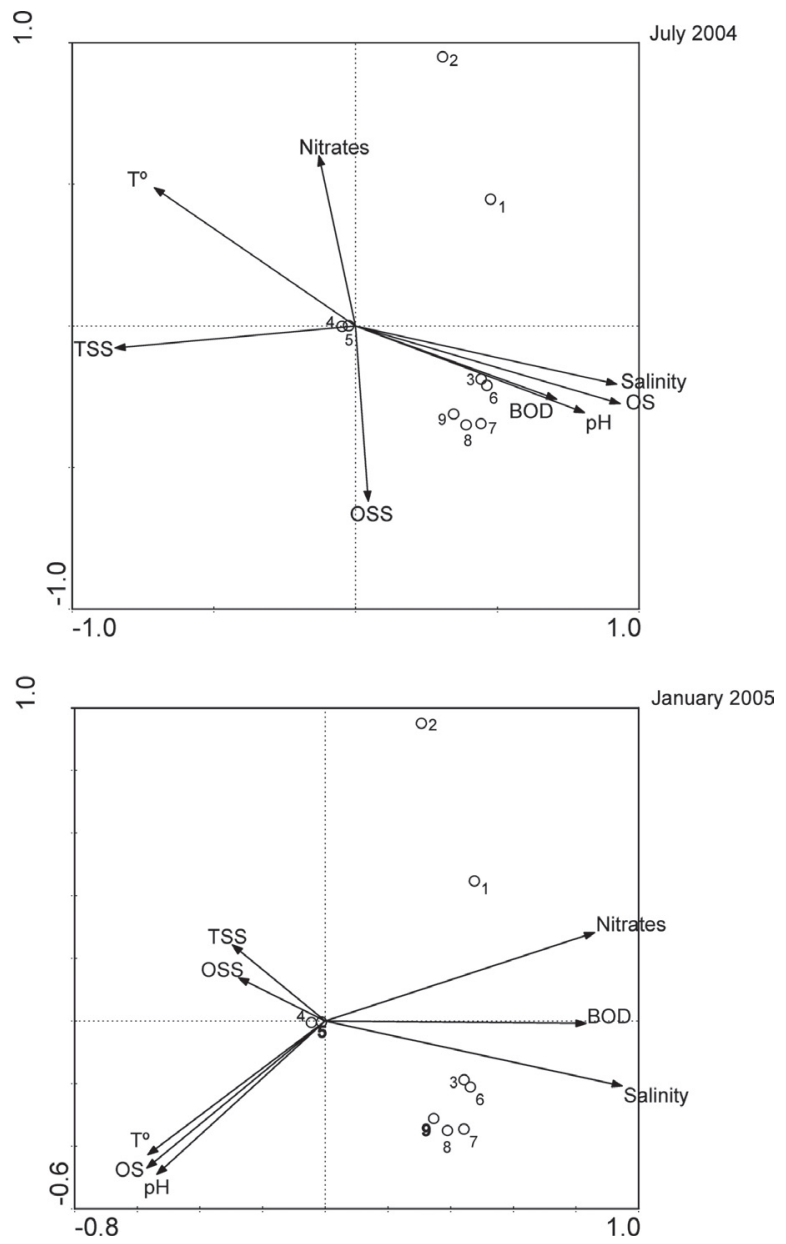

Fig. 3: Influence of the chemical variables in July (winter) and January (summer) on each monitoring station. $\left(\mathrm{T}^{\mathrm{0}}=\right.$ temperature, $\mathrm{OS}=$ oxygen in solution, $\mathrm{BOD}=$ biochemical oxygen demand, $\mathrm{TSS}=$ total solids in suspension, OSS $=$ organic solids in suspension)

\section{Phytoplankton composition in the winter period}

A total of 30 taxa during winter sampling were identified (Table 1). The most abundant group were the Bacillariophyceae Class (Diatoms), followed by the Cryptophyceae, Cyanophyceae, Chlorophyceae and Euglenophyceae (Fig 4). Within the diatoms group, the most abundant species were Tabellaria sp., Fragilaria sp., Girosygma spencerii and Aulacoseira sp. the abundance of the latter being $2.05 \times 10^{6}$ cell/ $\mathrm{L}$ in the Comué station (Fig. 2). The marine diatom Chaetoceros sp., occurred only in the Deume 3 station, indicating the influence of the sea in this area of the lake. The highest concentration of organisms was recorded in the Comue station: $2.164 \times 10^{6}$ cell/ $\mathrm{L}$, and the smallest in the Botapulli station: $8.56 \times 10^{4}$ cell/L.

Two species of Cryptophyceae were identified, Cryptomonas sp. was present in all the stations, being most abundant in Río Budi station, with $7.38 \mathrm{X} 10^{4} \mathrm{cell} / \mathrm{L}$. The group of Cyanophyceae was also present in all the stations, and the most abundant genera were Oscillatoria sp., Lyngbya sp. and Anabaena sp. On the other hand, the Euglenophyceae was present in all station except Bolleco, and it was only represented by the genus Euglena, which is considered as an indicator of water rich in organic matter. Finally, the Chlorophyceae group was only recorded in the Río Budi, Temo, Allipén, Comué, Deume 2 and Deume 3 stations, the most abundant species of this algal group was Scenedesmus quadricauda.

Phytoplankton composition in the summer period

A total of 34 taxa during the summer period were identified (Table 1). As in winter, the predominant phytoplankton group was the Bacillariophyceae, followed by the Cyanophyceae, Cryptophyceae, Chlorophyceae, Dynophyceae and Euglenophyceae (Fig. 4). The greatest abundance of diatoms was again recorded in the Comue station, represented in this case by the species Melosira varians, with a concentration of $9.18 \times 10^{6}$ cell/L. There is an increase in the number of taxa belonging to this group in the phytoplankton community of the lake. It should be stressed that the total concentration of algae during this period was greater than that recorded for July in all the stations monitored, with a maximum of $9.576 \times 10^{6}$ cell/ $\mathrm{L}$ in the Comue station, and a minimum of $6.508 \times 10^{4}$ cell/L in Deume 3.

The Cyanophyceae group, present in all the stations in the previous period, was not recorded in the Comué and Bolleco stations, and reached maximum abundance in the Río Budi station, with $1.84 \times 10^{5}$ cell/L. Meanwhile the greatest abundance of Cryptophyceae was recorded in the Deume 1 station, with $1.27 \times 10^{5}$ cell/L, but it was not recorded in the Río Budi, Temo, Comué and Bolleco stations. The Chlorophyceae $\mathrm{p}$ was more abundant than in winter, with the greatest concentration of organisms recorded at the Temo station, while no individuals of this algal group were recorded in the Río Budi, Bolleco, Deume 2 and Deume 3 stations. The Dynophyceae group, for which there had been no records in the winter, also appeared in the phytoplankton community, although both this group and the Euglenophyceae were present only in a few stations and in low abundance.
July 2004

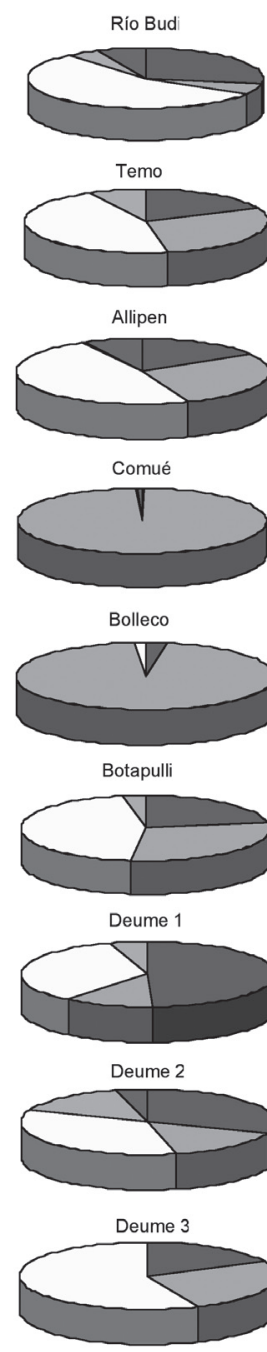

Cyanophyceae Bacillariophyceae Cryptophyceae
January 2005

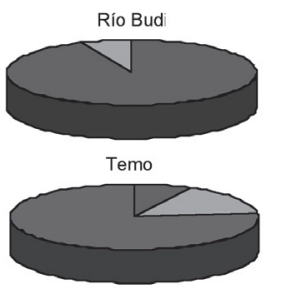

Allipen

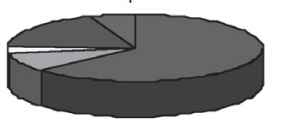

Comué

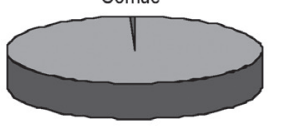

Bolleco

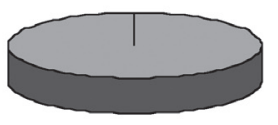

Botapulli

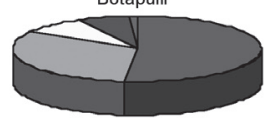

Deume 1

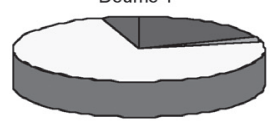

Deume 2

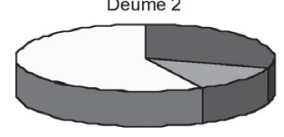

Deume 3

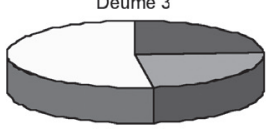

Chlorophyceae Euglenophyceae Dinophyceae
Fig. 4. Abundance of phytoplankton groups present in Lake Budi during July 2004 and January 2005. 
Table 1. Species present among the phytoplankton of the Lake Budi during the sampling periods.

\begin{tabular}{|c|c|c|c|c|c|c|c|c|c|c|c|c|c|c|c|c|c|c|}
\hline & \multicolumn{2}{|c|}{ Río Budi } & \multicolumn{2}{|c|}{ Temo } & \multicolumn{2}{|c|}{ Allipen } & \multicolumn{2}{|c|}{ Comué } & \multicolumn{2}{|c|}{ Bolleco } & \multicolumn{2}{|c|}{ Botapulli } & \multicolumn{2}{|c|}{ Deume 1} & \multicolumn{2}{|c|}{ Deume 2} & \multicolumn{2}{|c|}{ Deume3 } \\
\hline & $\begin{array}{l}\text { July } \\
2004\end{array}$ & \begin{tabular}{|c} 
January \\
2005
\end{tabular} & $\begin{array}{l}\text { July } \\
2004\end{array}$ & \begin{tabular}{|c|} 
January \\
2005
\end{tabular} & $\begin{array}{l}\text { July } \\
2004\end{array}$ & $\begin{array}{c}\text { January } \\
2005\end{array}$ & $\begin{array}{l}\text { July } \\
2004\end{array}$ & \begin{tabular}{|c|} 
January \\
2005
\end{tabular} & $\begin{array}{l}\text { July } \\
2004\end{array}$ & \begin{tabular}{|c|} 
January \\
2005
\end{tabular} & $\begin{array}{l}\text { July } \\
2004\end{array}$ & $\begin{array}{c}\text { January } \\
2005\end{array}$ & $\begin{array}{l}\text { July } \\
2004\end{array}$ & $\begin{array}{c}\text { January } \\
2005\end{array}$ & $\begin{array}{l}\text { July } \\
2004\end{array}$ & \begin{tabular}{|c|} 
January \\
2005 \\
\end{tabular} & $\begin{array}{l}\text { July } \\
2004\end{array}$ & $\begin{array}{c}\text { January } \\
2005\end{array}$ \\
\hline \multicolumn{19}{|l|}{ Cyanophyceae } \\
\hline Anabaenopsis elenkinii & & & & & & & & & & & + & & & & & & & \\
\hline Anabaena variabilis & + & & & + & + & + & + & & & & + & & + & & & & + & \\
\hline Lyngbya sp. & + & & + & + & & + & & & + & + & + & & + & + & + & + & + & \\
\hline Oscillatoria sp. & + & + & + & + & + & + & + & & + & + & + & & + & + & + & + & + & \\
\hline Nodularia spumigena & + & & + & & & & & + & + & & + & & + & + & & + & + & \\
\hline \multicolumn{19}{|l|}{ Bacillariophyceae } \\
\hline Asterionella formosa & & & & & + & & + & & & & + & & & & & & & \\
\hline Aulacoseira granulata & 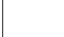 & & & & & & & & & & & & & + & & & & \\
\hline Aulacoseira sp & + & & + & & + & & + & + & + & & + & & + & & + & & + & \\
\hline Chaetoceros sp. & & & & & & & & & & & & & & & & & + & \\
\hline Cocconeis placentula & + & + & & + & + & + & & & & & & & & & + & & & \\
\hline Coscinodiscus sp. & & + & & & & + & & & & & & + & & & & & & \\
\hline Cyclotella sp. & & & + & 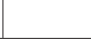 & & & & & & & & & & & + & & & \\
\hline Cymbella sp. & & & + & + & & & + & & & & & & & & & & & \\
\hline Epithemia adnata & & & & & & + & & & & & & & & + & & & & \\
\hline Fragilaria acus & & & & & & + & & & & & & & & & & & & \\
\hline Fragilaria sp. & & & + & + & + & & & & + & & + & & + & + & & & + & \\
\hline Tabellaria sp. & & & + & + & & & + & & + & & + & & + & & + & + & + & \\
\hline Fragilaria ulna & + & & + & 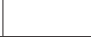 & & & & & & & & + & + & + & + & + & + & \\
\hline Gomphonema acuminatum & & & & + & & & & & & & & & & & & & & \\
\hline Gyrosigma fasciola & & & & + & & & & & & & & & & & & & & \\
\hline Girosygma spencerii & + & & + & + & & + & + & + & + & + & + & + & + & + & + & & + & \\
\hline Melosira numuloides & & & & & & + & & & & + & & & & + & & + & & \\
\hline Melosira varians & 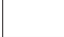 & & & + & & - & & + & & + & & & & + & & + & & + \\
\hline Navicula spp. & + & + & + & + & + & + & + & & + & + & + & & + & & + & & + & \\
\hline Nitzschia paradoxa & & + & & + & & + & & & & & & & & & & & & \\
\hline Nitzschia sigmoidea & & & & + & & + & & . & & + & & & & & & + & & + \\
\hline Nitzschia sp. & & & & & & & & & & & & & & + & & + & & + \\
\hline Pinnularia major & & & & & & & & + & & & & & & & & & & \\
\hline Rhopalodia musculus & & & & & & + & & & & & & & & & & & & \\
\hline Surirella ovata & & + & + & + & & + & + & & & & & + & + & & & & & \\
\hline Surirella sp. & & & & + & & & + & & & + & + & + & & & & + & + & \\
\hline \multicolumn{19}{|l|}{ Cryptophyceae } \\
\hline Cryptomonas & & & & & & & & & & & & & & & & & & \\
\hline Rhodomonas lacustris & & & & & & & & & & & & & & & & & & \\
\hline Euglenophyceae & & & & & & & & & & & & & & & & & & \\
\hline Euglena sp. & + & & + & + & + & + & + & & & & + & & + & & + & & + & \\
\hline Phacus & & & & + & & & & & & & & & & & & & & \\
\hline Dinophyceae & & & & & & & & & & & & & & & & & & \\
\hline Peridinium sp. & & & & & & + & & & & & & & & & & & & \\
\hline Chlorophyceae & & & & & & & & & & & & & & & & & & \\
\hline $\begin{array}{l}\text { Coelastrum } \\
\text { psudomicroporum }\end{array}$ & & & & & & & & & & & & & & + & & & & \\
\hline Cosmarium sp. & & & & & & & & & & & & & & & & & & \\
\hline Closterium aciculare & & & & + & & & & & & & & & & & & & & \\
\hline Eudorina elegans & & & & & & & & & & & & & & & & & & \\
\hline Oedogonium sp. & + & & + & - & & & & & & + & + & & + & & & & + & \\
\hline Pediastrum duplex & & & & + & & & + & & & & & & & & & & & \\
\hline Scenedesmus acuminatus & & & & + & & & & & & & & & & & & & & \\
\hline Scenedesmus ecornis & + & & + & & + & & + & & & & & & & & + & & & \\
\hline Scenedesmus quadricauda & + & & & + & + & & + & + & & & & & & + & + & & & \\
\hline Staurastrum sebaldii & & & + & & & & & & & & & & & & & & & \\
\hline Spirogyra sp. & & & & + & & + & & & & & & + & & & & & & \\
\hline
\end{tabular}




\section{Diversity}

During July 2004, the diversity of the phytoplankton in Lake Budi presented a wide variation between stations, fluctuating between a minimum of 0.132 in the Comué station and a maximum of 0.938 in the Temo station (Fig. 5).

In January 2005, the values for the diversity index fluctuated between 0.095 and 0.905 , with the highest and lowest indices again being at the Comué and Temo stations respectively. The phytoplankton diversity during this period diminished in all the stations, with the exception of Bolleco, where an increase in the index as against July 2004 was observed (Fig. 5).

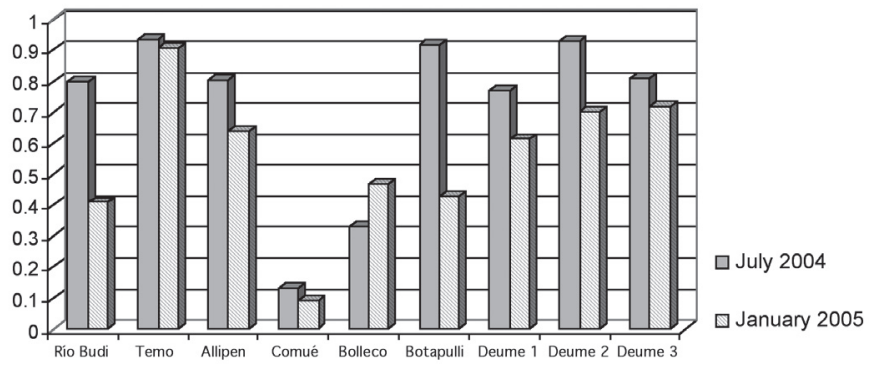
2005 .

Fig. 5: Phytoplankton diversity in Lake Budi during July 2004 and January

\section{DISCUSSION}

Based on the results obtained, it can be established that the physical and chemical characteristics of the water in Lake Budi vary according to the time of sampling, and that the variations are dependent on the parameter under analysis. However in terms of water quality, the concentrations of the parameters analysed would indicate that the quality of this lake is good, and indeed could be classified in the category of exceptional for surface water [25].

Nevertheless in the summer period, with the increase in temperature and the higher concentration of organic material, especially in the Río Budi, Botapulli, Deume 1, 2 and 3 stations, the concentration of oxygen in the water is reduced, resulting in reduced water quality.

With respect to the phytoplankton communities, although the Bacillariophyceae or diatom group remains dominant in the lake during both winter and summer periods, there are differences between the two periods, which are expressed in the species which dominate the communities and in their presence in the different sampling stations. This provides evidence that the modifications of the limnological conditions in the body of water influence and allow the development of the different components of the phytoplankton communities during the periods analysed.

This influence of the physical and chemical parameters was clearly reflected in the statistical analysis, which shows the relationship between the diatoms and the environmental variables considered. These data indicate a high correlation during July 2004 between the distribution of the diatoms and the salinity and oxygen in solution variables, while during the summer of 2005 the variables which have the greatest influence on the diatoms of Lake Budi are BOD, nitrates and salinity. It should be mentioned that the parameters for inorganic solids in suspension and phosphates were also analysed in this study, however they were not considered in the analysis of the results since they constitute co-variables of the other environmental parameters, making the execution of the statistical analyses more unstable.

The reduction in salinity during the winter period, resulting from an increase in precipitation and a greater inflow of water from the lake's tributaries, seems to be a determining factor for phytoplankton communities during this period, and thus having an important influence on the species of which they are composed. The presence of the marine diatom Chaetoceros $\mathrm{sp}$. in the Deume 3 station shows of marine influence in the lake in this period. Furthermore, the greater values for salinity recorded in the Río Budi, Allipén, Botapulli, and Deume 1, 2 and 3 stations would enable us to indicate that these areas of the lake receive a greater marine influence during the periods of sea water intrusion. On the other hand, the high salinity values recorded in the summer would be attributed to a concentration process of the salts in the water column, since there are high rates of evaporation in Lake Budi during summer.
The variations of the physical and chemical parameters in Lake Budi would also reflect the fact that the limnological conditions in the lake are not spatially homogenous, since differences were observed not only between the different sampling periods, but also between the different stations analysed.

In this regard, the grouping analysis for both sampling periods indicates that the clustering of the most of the stations depend of the study period, but the Comue and Bolleco stations remain together and separated from the others. This probably results from the lower exposure of these two stations to marine influence, which is supported by the low salinity values recorded in both sampling periods, and also by the location of these sites in the lake.

\section{ACKNOWLEDGEMENTS}

The authors of this study are grateful for the financial support of FONDECYT Project 1030861. Integrated Analysis of the Coastal Rim of the IX Region, Proposals and Criteria for the Ecological Planning of the Wetlands.

\section{REFERENCES}

1. G. E. Hutchinson, "A treatise on limnology, Vol. II, Introduction to lake biology and the limnoplankton", ed. by Wiley and Sons, New York. (1967).

2. C.S. Reynolds, "The ecology of freshwater phytoplankton", Cambridge University Press, Cambridge. (1984).

3. U. Sommer, "Plankton ecology; Succession in Plankton Communities", ed. by Springer-Verlag, Berlin. (1989).

4. V.L. De M. Huszar and N. Caraco, Freshwater Biology. 40 (1998) 679

5. K. Benson-Evans, R. Antoine and S. Antoine, Aquatic Conservation. 9 (1999) 425.

6. D. Tilman, "Resource competition and community structure", ed. by Princeton University Press, New York. (1982).

7. B. Moss, S. McGowan and L. Carvalho, Limnol. Oceanogr. 39 (1994) 1020 .

8. E.J. Philips, M. Cichra, K. Havens, C. Hanlon, S. Badylak, B. Rueter, M. Randall and P. Hansen, J. Plankton Res. 19(1997) 319

9. S.R. Carpenter and J.E. Kitchell, "The trophic cascade in lakes", ed. by Cambridge University Press, New York. (1993).

10. U.T. Hammer, "The plankton communities of saline lakes", in "Saline Lake Ecosystem of the World", ed. by W.Junk Publishers, Dordrecht. (1986) 171-336.

11. J.W. Day, C.A.S. Hall, W.M. Kemp and A.Y. Arancibia, "Estuarine Ecology", Wiley-Interscience, New York. (1989).

12. G.O. Kirst, "Influence of salinity on algal ecosystems, in "Algae, Environment and Human Affairs, ed. by W. Wiessner, W. Schnepf and R.C. Starr, Biopress Limited, Bristol. (1995) 123-142.

13. C.S. Reynolds, Holartic Ecology. 3 (1980) 141

14. K.L. Seip and C.S. Reynolds, Limnol. Oceanogr. 40 (1995) 589.

15. R. Wetzel. "Limnología", Editions Omega S.A., Barcelona- España. (1981).

16. Bertran C., Vargas L., Peña-Cortés F., Hauenstein E., Schlatter R. \& Durán T. Características texturales y estructura comunitaria de la microinfauna bentónica del lago costero Budi. Región de la Araucanía, Chile. (2004). In preparation.

17. Manual del Agua; Su Naturaleza, Tratamiento y Aplicaciones. Nalco Chemical Company. 7 (1993) 1-33

18. Norma Chilena de Agua Potable. 409, Of. 70, 7/1 Instituto Nacional de Normalización. Ministerio de Obras Públicas. República de Chile, Santiago, Decreto No 354

19. Standard Methods for the Examination of Water and Wastewater. APHA, AWWA and WPLF. Ed. 18 (1992)a. 2-56 ; (1992)b. 4-100 ; (1992)c. 485.

20. Uthermöhl, H. Zur Vervollkommung der quantitativen PhytoplanktonMethodik. Mitt. Int. Vereinigung Theor. Angew. Limnol. 15 (1958) 158163.

21. K. Kramer and H. Lange-Bertalot, Bacillariophyceae, in "Sü $\square$ wasserflora von Mitteleuropa, Band 2, ed. By H. E.ttl, J. Gerloff, H. Heynig and D. Mollenhauer, Gustav Fischer Verlag, Stuttgart, (1986-1991).

22. O. Parra, M. González, V. Dellarossa, P. Rivera and M. Orellana. Manual taxonómico del fitoplancton de aguas continentales con especial referencia al fitoplancton de Chile. Editorial Universidad de Concepción. Vol. I Cyanophyceae. (1982) 70. 
23. O. Parra, M. González, V. Dellarossa, P. Rivera and M. Orellana. Manual taxonómico del fitoplancton de aguas continentales con especial referencia al fitoplancton de Chile. Editorial Universidad de Concepción. Vol. III: Chyptophyceae, Dínophyceae y Euglenophyceae. (1982) 99.

24. O. Parra, M. González, V. Dellarossa, P. Rivera and M. Orellana. Manual taxonómico del fitoplancton de aguas continentales con especial referencia al fitoplancton de Chile. Editorial Universidad de Concepción. Vol. V: Chlorophyceae, Parte 1: Volvocales, Tetrasporales, Chlorococcales y Ulothricales. (1982) 151
25. CONAMA, Instructivo Presidencial de Normas Secundarias de Calidad Ambiental para Aguas Continentales Superficiales y Marinas (2002). 
J. Chil. Chem. Soc., 51, № 3 (2006) 